\title{
刺激文によって喚起される不快感情の分析 ${ }^{1}$ 一感覚モダリティと性の要因の効果一
}

$\begin{array}{lllll}\text { 名古屋大学文学部 } & \text { 过 } & \text { 敬一郎 } \\ \text { 東海学園女子短期大学 } & \text { 奥 } & \text { 田 } & \text { 達 } \\ \text { 愛知 淑徳短期大学 } & \text { 高 } & \text { 橋 } & \text { 啓 } & \text { 介 } \\ \text { 茨城大学人文学部 } & \text { 伊 } & \text { 藤 } & \text { 哲 } & \text { 司 }\end{array}$

Analyses of the discomforts aroused by stimulus sentences with reference to effects of modality and gender

\author{
Keiichiro Tsuji Nagoya University, Nagoya \\ Tatsuya Okuda Tokaigakuen Women's Junior College, Nagoya \\ Keisuke Takahashi Shukutoku Junior College, Nagoya \\ Tetsuji Ito Ibaraki University, Mito
}

This study attempted to analyze discomforts in relation to sensory modality and subject's gender. Twenty students were asked to give free description of the experiences they imagined with twenty-seven sentences depicting the situations of a distinct stimulation of four sensory modalities except for gustation. They were also required to rate on the five-point scale their judgments of easiness for reproducing the corresponding situation, easiness for arousing discomfort, and intensity of the discomfort, respectively.

Discomforts were divided into "sensation-based affect" and "cognition-based affect": The former is the affect induced directly by sensory event, as exampled by "I fear darkness itself" to a stimulus sentence "Make a night journey alone", whilst the latter is the affect aroused through cognitive processing, as exampled by "I get a fright by thinking I may be assaulted". Also, discomforts judged as indicating the potentiality for coping behaviour were checked to count their frequency. These judgments were made by experimenters.

The results obtained were as follows: 1) There found no significant difference among modalities and genders, in easiness for recollecting the situation and easiness for arousing the discomfort. 2) In all of the four modalities, sensation-based affect was aroused more frequently than cognition-based one. More closely, sensation-based affect was significantly dominant in tactual and olfactory modalities, whilst frequency of cognition-based one was relatively high in both visual and auditory modalities. Females gave larger number of reports on cognitionbased affect than males did. 3) Intensity of sensation-based affect showed main effects of two variables and their interaction, whilst that of cognition-based affect showed the modality effect alone. Intensity of sensation-based affect was higher in audition and olfactions, while that of cognition-based affect was the highest in vision. 4) Potentiality for coping behaviour was higher for sensation-based affect than for cognition-based one. Intensity was higher for the discomfort showing the potentiality than for the discomfort showing no sign of it.

Key words: discomfort, sensory modality, sensation-based affect, cognition-based affect

問 題

感情・情動は，生体の内環境の情報処理過程
であり，感覚・知覚など外環境の情報処理過程 とともに行動的適応を理解する上に重要な意識

1. 本研究は, 平成 5 年度文部省科学研究費補助重点領域研究「感性情報処理の情報学・心理学的研究」(領域代表者 : 迲三郎) C斑の計画研究（代表者：中谷和夫，分担者：过敬一郎）の一部として実施した。 
現象だと考えられる。それにもかかわらず，本 来は連続的な過程とみなすべき意識と行動の問 題を統合的に扱う試みが進展することなく，問 題史においても両者は相互に関連づけられるこ とのないままに検討されてきた（内山，1984； 辻, 1985, 1993)。感情・情動分野が感覚・知覚 分野と異なる学問的系譜に属していた上に，感 覚・知覚が概して外部刺激の物理的尺度に対応 づけて扱われるのに対し，感情・情動の場合は そのような対応づけが困難だといら方法上の問 題がつきまとうところから，研究における両者 の乘離を招いているのだと思われる。

従来, 感情研究の多くは, 静止画像または動 画を刺激として特定の感情を喚起させ，その特 性を心理的・行動的・生理的測度によって捉え てきた (Frijda, 1988; Uchiyama, et al., 1990; Plutchik, 1992)。このパラダイムでは, すべて の被験者に同一の感情的事態を呈示するために 反応の解釈が容易である反面，刺激が複雑なた めに喚起される感情の種類や強度に個人差が大 きい。その上に，感情・情動事象を感覚・知覚 事象と関連づけて論じることが難しく，また， 視覚以外のモダリティによって喚起される感情・ 情動を扱うことができないといら問題もある。

そこで，それらの難点を補うために，本研究 では，画像刺激によって感情を喚起させるのと は異なる手法を採用した。すなわち，不快感情 を喚起すると考えられる感覚事象を表わした刺 激文を被験者に与え，喚起される経験について 内容を口述させるとともに，場面想起や感情喚 起についても評定を求め, それらの結果につい て分析した。この手続きは文章呈示による一種 の「代理刺激法」であり，画像刺激法に比べる と刺激が間接的である上に，反応に高い自由度 が与えられているので，想起される場面に個人 差が生じることは避けられない。しかしながら， 感覚モダリティを考慮した刺激事態の設定が可 能であるので, 喚起される感情を個別モダリティ と関連づけて検討できるという利点をもつ。扱 ら刺激事態を不快の喚起事態に限ったのは，快 に比べて不快は概して行動喚起力が大きく，刺
激強度と表出行動の対応がかなり一義的だと考 えられるからである。

本研究では, 刺激事態の感覚モダリティと被 験者の性をそれぞれ主変数として検討するが， その場合, 生じた不快感情を, 被験者の言語反 応にもとづいて，それが刺激事態から直接に喚 起されたものか, なんらかの認知的処理を介し て生起したものかに分類することにした。たと えば「暗い夜道を独りで歩く」という刺激文(本 実験の刺激文 1）が与えられた場合，暗闇が怖 いと感じる場合と他人から襲われるかもしれな い不安を感じる場合とでは，不快が喚起される 過程に違いがあると考えた。そこで, 前者を「感 覚性感情」(sensation-based affect)，後者を「認 知性感情」(cognition-based affect) と名づけ て，両者の強度関係やモダリティ特性について も併せて検討した。現段階ではこの区別は暫定 的であり，今後の研究によって精繳化されなけ ればならないが,感情喚起過程を感覚モダリティ との関連で検討する上で有効だと考えて導入す ることにした。

いま一つの試みとして，「行動化傾向」 (behavioural tendency) という測度を設けた。 この測度は，「気分が悪くて逃げ出したい」など のように，被験者の口述内容加ら不快感情に対 してなんらかの行動的対処が読み取れる場合を さす。もとより実際の表出行動を問題にできる わけではないが,このようにして潜在的な行動 化傾向をチェックし，それを上述の感情種別と 関連づける意義は大きいと考えた。

以上のように, 本研究は, 感覚・知覚系一感 情・情動系一行動系を連続過程として統合する モデルを定立するための基礎であり，今回の試 みは，感情喚起を感覚事象と関連づけて検討す るためのパイロット・スタディである。現段階 では明確な仮説を提示することはできないが， この種の事象に関与する可能性があると思われ る性や年齢の要因についても，その効果を吟味 しておくことが必要だと考えた。そのうち年龄 要因の検討は今後に譲るとして，ここでは大学 生男女を対象に資料を収集し，感覚モダリティ 
と被験者の性を主変数とした分析をおこなうこ とにした。

\section{方 法}

\section{被験者}

大学生20名（男女各10名，19～24歳）。被験者 はいずれも心理学専攻生で, ヴォランティアと して実験に参加した。

\section{刺激}

(1)選定：予備調査で, 視・聴・触・㖵・味覚の 5 種の感覚モダリティにつき, 不快感情を喚起 すると予測される事態を取り上げて, その記述 文（各モダリティ10種）を呈示して，喚起され る感情につき評定を求めた。その結果, $60 \%$ 以 上の被験者が「不快」としたものを刺激文とし た。選定されたのは味覚を除く 4 種のモダリティ の計27事態であった。

(2)刺激文：表 1 に示すように，上記 27 事態に練 習用の 2 事態を加えた計29の刺激文を用いた。 刺激文27個の内訳は，視覚 (V) 8 個, 聴覚 (A) 7 個, 触覚 (T) 5 個, 咱覚（O） 7 個である。 手続き

(1)概要：実験は 1 日に 1 セッションとし，2 日 間にわたって実施した。第 1 セッションでは 12 文、第 2 セッションでは15文を呈示し，ロール シャッハ・テストの実施要領に準じ，実験者が 刺激文を読み上げて被験者に自由口述させ，当 該セッションの刺激文すべてに対する口述が終 了した後, 質疑にもとづく補足説明と所定の評 定を求めた。なお，第 1 セッションに限って最 初に 2 個の刺激例文を用いて練贸をおこなった。 被験者の発語は実験者がその場で筆記するとと もに，テープに収録して，必要に応じ再生して 筆記を補った。

(2)自由口述：実験者が刺激文を順次読み上げ， その場面，および随伴して体験される感情につ いて自由に口述するよう被験者に求めた。各刺 激文ごとに発語潜時（初発反応時間）を計測し， 併せて口述を逐語記録した。なお，場面を想起 しやすくするために，セッション中は閉眼する よう指示した。
表 1 実験に用いた刺激文

\begin{tabular}{|c|c|c|}
\hline 番号 & 刺＼cjkstart激 & 感覚 \\
\hline E 1 & 夜中に突然電話のベルが鳴る & 聴覚 \\
\hline E 2 & 交通事故の現場を目撃する & 視覚 \\
\hline 1 & 暗い夜道を独りで歩く & 視覚 \\
\hline 2 & 消防車のサイレンを聞く & 聴覚 \\
\hline 3 & ヌルヌルした魚を素手でつかむ & 触覚 \\
\hline 4 & 人混みで汗の臭いを嗅ぐ & 嗅覚 \\
\hline 5 & 食器の割れる音を聞く & 聴覚 \\
\hline 6 & 生ゴミの臭いを嗅ぐ & 嗅覚 \\
\hline 7 & ビルの屋上から地面を見下ろす & 視賞 \\
\hline 8 & 黒板を引择く音を聞く & 聴覚 \\
\hline 9 & ニンニクの臭いを嗅ぐ & 嗅覚 \\
\hline 10 & 人の悲鳴を聞く & 聴賞 \\
\hline 11 & ナフタリンの臭いを嗅ぐ & 嗅覚 \\
\hline 12 & 真っ暗な押入に閉じこめられる & 視覚 \\
\hline 13 & 生魚の臭いを嗅ぐ & 嗅覚 \\
\hline 14 & エレベータに独りで閉じこめられる & 視覚 \\
\hline 15 & 電車の中で他人と身体が触れ合う & 触覚 \\
\hline 16 & 鉛筆の先を自分の顔に向けられる & 視覚 \\
\hline 17 & 蝶を指でつまむ & 触賞 \\
\hline 18 & 他人が怪我で血を流しているのを見る & 視覚 \\
\hline 19 & ガムをクチャクチャ粬む音を聞く & 聴覚 \\
\hline 20 & タバコの臭いを嗅ぐ & 嗅覚 \\
\hline 21 & 動物が解剖されているのを見る & 視覚 \\
\hline 22 & $\begin{array}{l}\text { マイクがハウリングする（キーンとい } \\
\text { う）音を聞く }\end{array}$ & 聴覚 \\
\hline 23 & 靴の中に砂が入る & 触覚 \\
\hline 24 & 強い香水の匂いを嗅ぐ & 嗅覚 \\
\hline 25 & 蛇が這っているのを見る & 視覚 \\
\hline 26 & 街頭宣伝車のスピーカの音を聞く & 聴覚 \\
\hline 27 & 雨で豉の毛が濡れる & 触覚 \\
\hline
\end{tabular}

注）E 1・E 2 は練習用。刺激文 1 １2を第 1 セッ ション，13〜27を第 2セッションで使用した。

(3)補足説明：自由口述内容につき若干の質疑を おこない，分析に必要と思われる点を明確にし， さらに被験者の自発的な説明を促した。

(4)評定：補足説明に続いて，刺激文ごとに，場 面想起と感情想起のそれぞれについて，想起が 「困難」(-2) 〜「容易」(+2) の5 段階, ま た，想起された感情の不快度（感情強度）につ いて,「平気」(0) 〜「非常に不快」（4）の 5 
段階で，それぞれ評定を求めた。なお，同一刺 激文に対する口述の中に不快感情が複数含まれ ると判断された場合には，それぞれについて評 定を求めた。さらに，刺激文に示されたのと同 様の経験が過去にあったか否か（経験の有無） についても回答を得た。

\section{データ処理}

（1)評定値：場面想起・感情想起の難易度と感情 強度は，被験者による評定値にもとづいて算出 した。

(2)感情種別：自由口述および補足説明の内容に もとづき，想起された不快感情が感覚性か認知 性かを，実験者 4 名（本研究担当者）が合議に より判定した。すなわち, 先に述べた分類に従っ て, 感覚性感情のみを含む場合, 認知性感情の みを含む場合をそれぞれ S，Cとし，両種の感 情を含む内容が報告されていると判断される場 合には，その出現順序に従って $\mathrm{S} / \mathrm{C}$ まはC／ $\mathrm{S}$ とた。なお, 感覚性と認知性に二分する場 合には， S/C，C/Sをそれぞれ S，Cに加 えて感情強度を算出した。

(3)行動化傾向：自由口述および補足説明の内容 から, 感情想起に伴ってなんらかの行動的対処 の可能性が認められるものを取り上げ，行動化 傾向ありと判断した。この判定にも4名の実験 者（本研究担当者）があたった。

\section{結 ·果}

上述の方法で得られた 6 種の測度についてモ ダリティごとの平均值を求め, 性差（2）とモ ダリティ（4）の2 要因分散分析を抗こなった。 ただし, 被験者のうち 1 名（女性）の場合は， 初発反応時間が甚だしく長い上に, 感覚性感情 と認知性感情の割合が他の被験者と著しく異なっ ていたために，今回の分析対象から除外するこ とにした。

\section{事態経倹の有無}

設定した27事態のそれぞれについて，経験の 有無をしらべた結果，「経験あり」と回答した被 験者の割合は，視覚 $70.8 \%$, 聴覚 $90.4 \%$, 触覚 $95.6 \%$ ，嗅覚 $93.5 \%$ であった。他のモダリティ
に比べて視覚の経験の割合が低いのは,「エレベー タの中で独り閉じこめられる」(0\%),「動物が 解剖されているのを見る」(44.4\%) が含まれて いることによる。しかし，それらの事態の想起 しやすさが他の事態に比べて低くなかったので, 以下の分析にあたって除外はしなかった。

\section{初発反忘時間}

図 1 のように, 初発反応時間の平均は男性が 女性より有意に長かった $(F=2.04, d f=1 / 500$, $p<.05)$ 。ダリティによる違いは認められなかっ た。

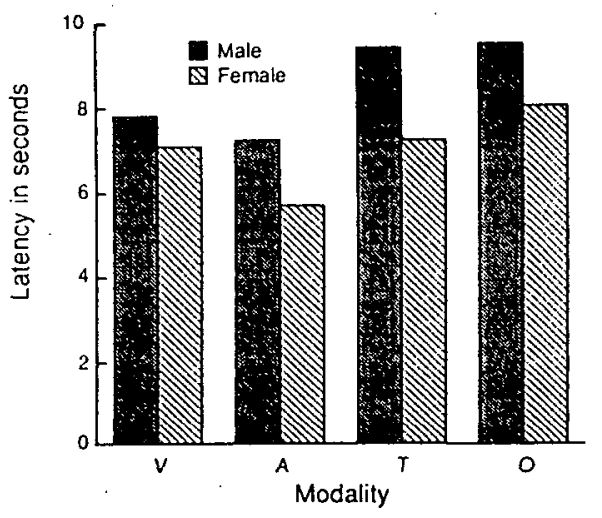

図 1 感覚モダリティおよび性と初発反応時間との関俰 $V:$ 視覚, $A ：$ 聴覚, $T:$ 触覚, $O:$ 嗅覚

ちなみに，事態の経験の有無別に求めた平均 時閒は，「経験あり」(8.48sec）が.「経験なし」 (12.08sec) より短い值であった。

\section{想起の難易度}

(1)場面想起の難易度 : 図 2 のよに, 場面想起 の難易度には，モダリティについてのみ傾向差 $(F=2.54, d f=3 / 503, p<.10)$ が認められ, 視覚・嗅覚が聴覚・触覚に比べて想起が困難で あることを示している。

(2)感情想起の難易度 : 図 3 に示すように, 感情 想起では，両要因およびその交互作用のいずれ についても有意な差が認められなかった。

\section{感情の種別}

先述のカテゴリに従って分類した感情種別の 出現率を図 4 に示す。全体的には，いずれのモ ダリティについても感覚性感情（S）の值が最 
CがSを上回っていた。

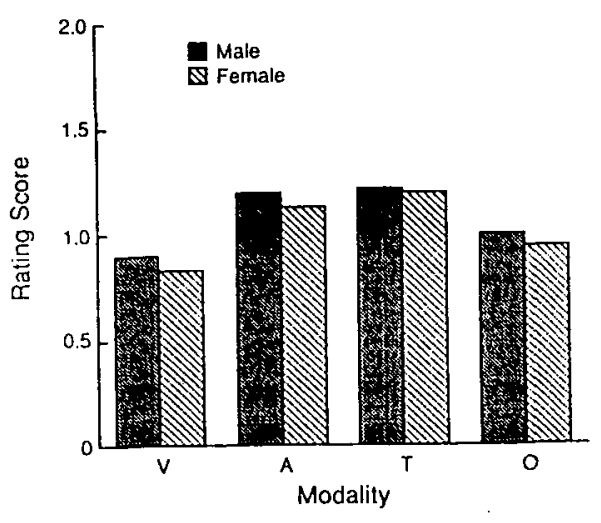

図2 感覚モダリティおよび性と場面想起難易度との関係 $\mathrm{V}:$ 視覚, $A$ : 聴営, $\mathrm{T}:$ 触覚, $\mathrm{O}:$ 嗅覚

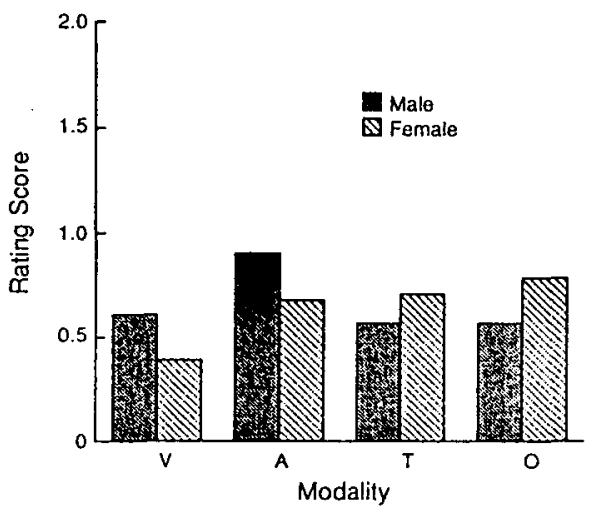

図3感覚モダリティおよび性と感情想起難易度との関係 $\mathrm{V}:$ 視覚, $\mathrm{A}$ : 聴覚, $\mathrm{T}:$ 触覚, $\mathrm{O}:$ 嗅覚

も高かった。これは，感覚刺激によって不快感 情を喚起させるように設定した刺激文が妥当で あったことを示すものである。

モダリティ別にみると, 感覚性感情（S）は, 視覚 $(51.3 \%)$ - 聴覚 $(59.3 \%)$ に比べて触覚 $(79.8 \%) \cdot$ 㖵覚 $(80.8 \%)$ で高率を占め, 逆に, 認知性感情 (C) の出現率は，視覚 $(35.6 \%)$. 聴覚 (21.4\%) で高かった。Sと S $/ \mathrm{C}, \mathrm{C}$ と $\mathrm{C} / \mathrm{S}$ をれぞれ加算した值でも，この傾向は 変わらない。

また，男性と女性を比べると，いずれのモダ リティでも，女性に拉いて認知性感情（CとC／ $\mathrm{S}$ の和）の出現率が高く，特に視覚に扔いては

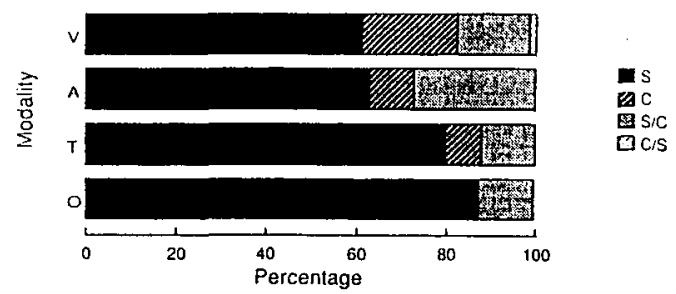

(a) Males

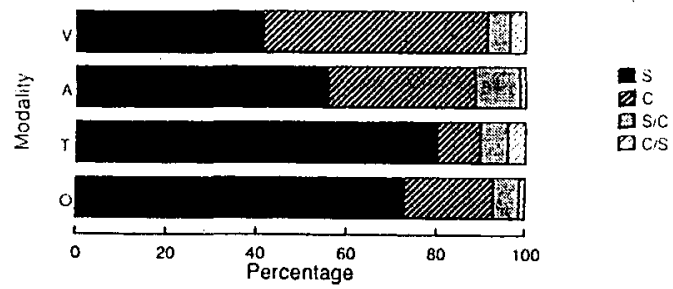

(b) Females

図4感覚モダリティおよび性と感情種別比率との関係 (a)は男性，(b)は女性を示す。 $V:$ 視覚, $A ：$ 聴覚, $T:$ 触覚, $O ：$ 嗅覚

\section{感情強度}

(1)感覚性感情の強度 : 結果を図 $5(\mathrm{a})$ に示す。強 度にはモダリティ $(F=5.76, d f=3 / 504, p<.01)$ および性（ $F=3.99, d f=1 / 504, p<.05)$ の 主効果で有意差, 両者の有意な交互作用 $(F=5.83$, $d f=3 / 504, p<.01)$ が認められた。モダリティ では，聴覚と嗅覚の強度が視覚に比べて有意に 高汃た（臨界值=3.65，df=504，p<.05）。 他方, 性では全体的に男性のほうが強度がやや 高いが，触覚のみ女性のほうが高かった（臨界 值 $=2.78, d f=504, p<.05)$ 。

(2)認知性感情の強度 : 結果を図 $5(\mathrm{~b})$ k示す。強 度は全体的に感覚性感情のそれよりも低い值で あったが, モダリティで有意差 $(F=7.91, d f=$ $3 / 504, p<.01)$ が認められた。下位検定によ れば, 視覚が触覚・嗅覚に比べ, 聴覚が嗅覚に 比べそれぞれ有意に高い強度であった(臨界值二 $3.65, d f=504, p<.05) 。$

\section{行動化傾向}

感覚性感情に伴う行動化傾向は24.9\%（男性 


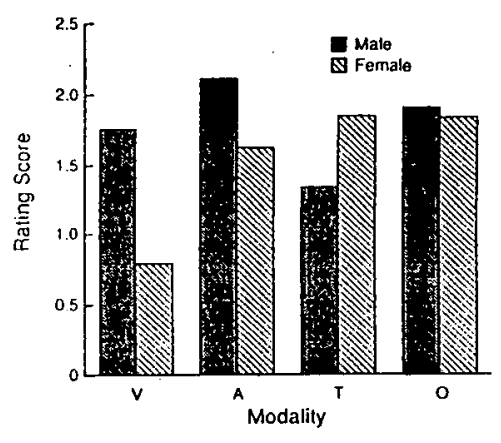

(a) Sensation-based affect

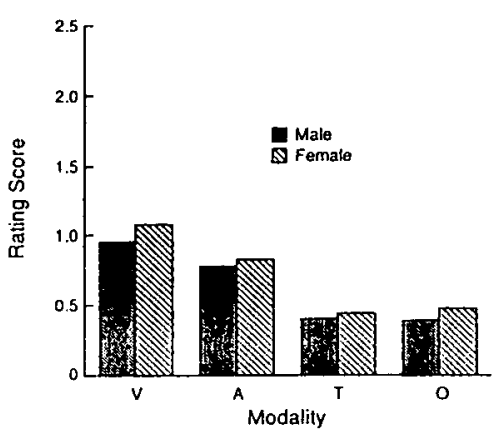

(b) Cognition-based affect

図 5 感覚モダリティ拉よ゙性と感情強度との関係 (a)は感覚性感情，(b)は認知性感情を示す。 $\mathrm{V}$ : 視覚, $\mathrm{A}$ ：聴覚， $\mathrm{T}$ : 触覚, $\mathrm{O}:$ 嗅覚

$12.7 \%$, 女性 $12.2 \%)$, 認知性感情に伴う行動化 傾向は6.2\%（男性1.4\%, 女性 $4.8 \%$ ) で, 前者 の值が高い $\left(x^{2}=49.08, d f=4, p<.01\right)$ こと が明らかになった。また, 感覚性感情では性差 が認められないのに対し，認知性感情では女性 のほうが行動化傾向が顕著 $\left(x^{2}=13.33, d f=2\right.$, $p<.01)$ であった。

行動化傾向の有無と場面想起・感情想起の難 易度との関連を検討した結果，表 2 に示すよう に，行動化傾向ありの場合の場面想起・感情想 起は, 行動化傾向なしの場合よりも有意に值が 高 <（場面想起 : $t=2.69, d f=405, p<.01$, 感 情想起 : $t=2.93, d f=406, p<.01)$, 行動化傾 向が想起のしやすさと関連していることを示し た。

行動化傾向の有無と感情強度との関倸につい ては, 表 2 のうに, 感覚性感情で, 行動化傾

向ありの場合の感情強度が有意に高かった $(t=$ $2.04, d f=405, p<.05)$ が, 認知性感情では行 動化傾向の有無による強度の差は認められなかっ た $(t=1.79, d f=405, n . s$.$) 。$

表 2 想起難易度および感情強度と行動化傾向 との関係

\begin{tabular}{lccc}
\hline & \multicolumn{3}{c}{ 行動化傾向 } \\
& あり & なし & 差 \\
\hline 場面想起の難易度 & 1.22 & 0.91 & $p<.01$ \\
感情想起の難易度 & 1.01 & 0.66 & $p<.01$ \\
感賞性感情の強度 & 2.22 & 1.93 & $p<.05$ \\
認知性感情の強度 & 0.73 & 0.96 & $n . s$. \\
\hline
\end{tabular}

\section{測度間の関係}

本研究で用いた測度のらち行動化傾向を除く 5 測度の間の相関関倸を表 3 に示す。

それによると, 初発反応時間と場面想起 - 感 情想起それぞれの難易度との間は負の相関関倸 にあったが, 感覚性感情強度と認知性感情強度 との間には相関が認められなかった。さらに, 初発反応時間は感覚性感情強度と負の相関を示 したが，認知性感情強度とは無相関であった。

\section{表 3 諸測度間の相関}

場面想起 感情想起 感覚性感 諗知性感 の難易度 の難易度 情の強度 情の強度

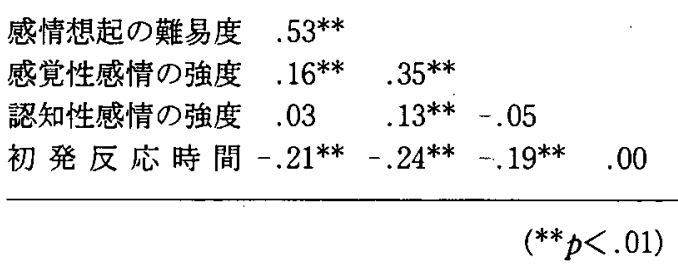

考 察

場面想起の難易は過去経験の有無によって異 なり，類似の事態を経験している場合のほうが 想起が容易だと評定され，初発反応時間も短かっ た。このことは, 被験者が刺激文呈示によって その場面での自身の感情体験を再現したことを 
示すもので, 本研究における操作の妥当性を裏 づけている。

感情想起の難易度は，モダリティ・性のいず れの要因でも差が認められなかったが, 感情を 感情性と認知性に二分してそれぞれの出現率お よび強度について検討した結果, 興味樑い所見 を得た。

寸なわち, 感覚性感情が認知性感情より総じ て出現率が高く，モダリティとの関連でみると， 感覚性感情の優位性は視覚・聴覚よりも触覚・ 嗅覚において顕著であった。喚起される感情の 強度をみると, 感覚性感情が認知性感情より高 く, その強度は視覚く聴覚く嗅覚（触覚はいず れとも有意な差を生じなかった）となり，視覚・ 聴覚では男性, 触覚では女性の感情強度が高かっ た。他方, 認知性感情の強度には性差がなく, 視覚 $>$ 聴覚 $>$ 触覚 $>$ 嗅覚の序列であった。この ように，モダリティに関して両種の感情強度は ほぼ逆の序列を示し, 相互補償的な関係が明ら かになった。

これらの所見から, 触覚・嗅覚では感覚経験 に随伴して不快が喚起されるのに対し, 視覚・ 聴覚ではなんらかの認知的処理を経て不快が経 験されやすいというモダリティ特性が示唆され る。なお，いくつかの点で性差が認められたが, その意味づけは今後の課題とし, 所見を示すに とどめたい。

また, 行動化傾向は, 場面・感情の想起しや すさと関連があることが明らかであったが，感 覚性感情の強度が行動化傾向と関連をもつのに 対し, 認知性感情の強度は行動化傾向の有無之 無関倸であった。この点については今後さらに 別の手法を導入して検討しなければならないが,
感覚経験によって喚起された感情が, 行動表出 に直接的に結びっく采と認知過程を解発する系 という，二重の過程を経て処理されるとする仮 説を示唆しているように思われる。

\section{引 用 文 献}

Frijda, N. H. 1988 The laws of emotion. American Psychologists, 43, 349-358.

Plutchik, R. 1993 The measurement of emotions and their derivatives. The paper presented at the 56th Annual Convention of the Japanese Psychological Association.

辻敬一郎 1993 行動空間の感性情報処理一視 覚性情動の特性分析一 文部省科学研究費重 点領域研究平成 4 年度成果報告書「感性情報 の情報学・心理学的研究」第 2 回全体会議予 稿集 $125-128$.

过敬一郎 1994 事態依存的感覚性感情の分析 文部省科学研究費重点領域研究平成 5 年度成 果報告書「感性情報処理の情報学・心理学的 研究」 139-142.

辻敬一郎 1995 空間性情動と空間的行動 文 部省科学研究費重点領域研究平成 6 年度成果 報告書「感性情報処理の情報学・心理学的研 究」 147-150.

内山道明 1984 知覚系一行動系の統一的理解 八の基礎的研究一その背景的構想 名古屋大 学文学部研究論集 $90,37-48$.

Uchiyama, I., Hanari, T., Ito, T., Takahashi, K., Okuda, T., Goto, T., and Tsuji, K. 1990 Patterns of psychological and physiological responses for common affects elicited by films. Phychologia, 33, 36-41. 